\title{
Banking Supervision in the Eurozone
}

The European Council agreed on 13 December to authorise the ECB to supervise the eurozone's important banks. The agreement on the Single Supervisory Mechanism (SSM) initially applies to all eurozone member states, but other EU countries can participate on a voluntary basis. Specifically, the ECB is authorised to supervise credit institutions that either:

- have total assets over $€ 30$ billion;

- have a balance sheet amount that exceeds 20 per cent of the member state's gross national income;

- are among the three most important credit institutions in a participating state; or

- receive direct support from the European Stability Mechanism (ESM).

These criteria apply to approximately 150 banks in the eurozone. ${ }^{1}$ Originally, a majority of the eurozone countries favoured a model that would make the ECB responsible for the oversight of all banks. However, the idea of universal oversight did not survive the subsequent discussion process within the European Union. In the final agreement, the supervision of all other banks remains with national supervisory authorities. The ECB may give general instructions but cannot interfere with the national authorities' actual monitoring of these less significant banks. Only if national authorities deviate from the uniform application of high supervisory standards does the ECB have the right to take over the direct supervision of certain banks.

National parliaments and governments are usually responsible for building the regulatory framework for banks and for controlling the agency that monitors enforcement. However, the ECB's constitution guarantees the eurozone's central bankers independence from governmental interference. Obviously, preserving the present governance structure would have triggered a conflict between the ECB's independence and the responsibility for banking supervision. Germany in particular insisted on a clear separation of banking oversight and the ECB's mandate for an independent monetary policy. In response to these concerns, the Council proposed a new supervisory board at the ECB that will consist of representatives from each participating country and five representatives from the ECB, including a member of the executive board. In cases of conflict between the ECB board and the new supervisory board, a new mediation panel with representatives from each of the participants will have final authority.

The two-tier structure may meet its objectives, at least on paper. In practice, however, only time will tell whether independence in monetary affairs and governmental control of supervisory activities can coexist under the common roof of the ECB. In any case, the new European supervisory authority will only gain authority if it can afford to hire personnel who are both highly qualified and independent. Prior to the financial crisis, supervisors, banks and politicians often demanded more frequent personnel exchange between banks and supervisory agencies. Now, however, caution is required in this respect. If the new supervisory staff is too close to the banking sector, this could have detrimental effects on its ability to effectively monitor and control the banks.

The SSM is the result of both the crisis and the lessons that nearly five years of crisis management have taught. National oversight is inadequate to effectively supervise financial conglomerates active on a European and global scale. Only a system that is unified at least at the European level will be able to better detect and sanction off-balance sheet activities and regulatory arbitrage that overlaps national borders and sectors. Currently in Europe, the national oversight agencies are often powerless against financial conglomerates. In terms of

1 http://www.bundesfinanzministerium.de/Content/DE/Standardartikel/Themen/Europa/ECOFIN_und Eurogruppe/2012-12-14-ecofin-nachbericht.html. 
regulatory oversight, the prevention of co-ordination failures in supervision requires a transnational mandate. This can only be achieved through the creation of a European financial market oversight system. ${ }^{2}$ The ECB's new mandate is clearly a step forward in achieving this goal, although the SSM only applies to the banking sector.

The fact that less important banks will continue to be supervised by national authorities does not represent a contradiction. The European Central Bank and its affiliated national central banks have already demonstrated that such a division of labour can work. Delegating the supervision of regional banks to national authorities and the monitoring of large supranational banks to the ECB corresponds to the principle of subsidiarity. The two-tiered system guarantees as little central oversight as necessary and as much local supervision as possible for implementing more co-ordinated regulation and bank oversight within Europe.

The European Banking Authority (EBA) will have to give up the supervision of banks that will be covered by the future mandate of the ECB. However, the EBA's role in the supervision of banks that remain within the jurisdiction of national authorities has not been sufficiently clarified yet. Will the EBA hold on to the competencies it only recently assumed for all European banks, such as conducting regular stress tests or suggesting technical standards to the EU commission? A new potential for co-ordination failure could arise if the ECB and EBA's tasks overlap to a high degree, but responsibility for each task is not sufficiently defined. In any case, the serious danger of supervisory co-ordination failure continues to exist with respect to financial conglomerates that conduct banking activities but are subject to either the European Securities and Markets Authority or the European Insurance and Occupational Pensions Authority, both of which were also established in 2011.

The introduction of the SSM is a necessary precondition for the ESM to be allowed to recapitalise banks directly. Currently only sovereign governments can receive loans from the ESM, which they then forward to ailing banks. During the crisis, when many governments were forced to assume more debt in order to bail out their over-indebted banks, investors grew wary of the capability of these countries to carry their debt burdens. Consequently, they often withdrew capital from these countries, which caused their interest rates to increase and the values of their sovereign bonds to decrease. Prior to the crisis, banks considered these bonds as nearly perfect substitutes for cash: stable in value, easily sellable and therefore highly liquid. Currently, however, downward pressure on many of these sovereign bonds has created the threat of a vicious circle. Due to the often high exposure of some banks to these bonds, their devaluation threatens the survival of the banks and forces them to ask for additional governmental support. Direct recapitalisation by the ESM could break this vicious circle, as the financial support would then be backed by all eurozone member states instead of just one country.

In exchange for its support, the ESM should require bank shares. If the bank recovers, European taxpayers would then participate in a bank's future value gains which they made possible. Despite the SSM, the German finance ministry will continue to be very cautious with regard to the direct recapitalisation of banks. However, overcoming the vicious circle is crucial for the enduring stabilisation of the eurozone, and at the moment, there is no better solution available.

The SSM still needs the approval of the European Parliament (EP). Most likely, the EP will struggle to avoid too much divergence between the EU as a whole and the eurozone. EP members may therefore concentrate their efforts on improving the direct access of banks to the ESM. Direct access is attractive, and making it easier would increase the likelihood that many EU countries outside the eurozone participate in the SSM.

DIW Berlin, Germany and Jönköping University, Sweden.
2 D. Schäfer: Agenda for a New Financial Market Architecture, Weekly Report 7, 2009, pp. 41-49, available at http://www.diw.de/sixcms/detail.php?id=diw_02.c.236407.de. 